\title{
ASSESSING THE ADOPTION OF CONSERVATION AGRICULTURE TOWARDS CLIMATE CHANGE ADAPTATION: A CASE OF NKOMAZI, MPUMALANGA PROVINCE
}

\author{
Sithole MZ* and Agholor AI \\ Faculty of Agriculture and Natural Sciences, School of Agricultural Sciences, University \\ of Mpumalanga, South Africa
}

\begin{abstract}
Climate change is a threat to agricultural productivity and the overwhelming effects of climate change hinders the quest for sustainable agriculture, with the aim of satisfying the increasing demands for food and fiber. Adaptation to the ever-changing climate is a necessity for the agricultural sector. The study was conducted in Nkomazi Local Municipality. The study assessed the adoption of conservation agriculture in relation to climate change by smallholder farmers. Focus group discussion, structured and semistructured questionnaires were used to randomly collect data from selected smallholder farmers. The data was analyzed using the binary logistics regression model to determine adoption behavior of farmers in the use of conservation agriculture. Logistic regression result show that several predictor variables were found to significantly influence the adoption behavior of smallholder farmers in the area. The study noted the existence of significant variables to include age, education, household size, income, number of children, and adoption of conservation agricultural practice. Marital status of the farmers was found not to be significant and never to influence the adoption behavior of farmers with a p-value of (0.911) and co-efficient of (0.102). Furthermore, thoughtful decision process and smallholder farmers' capacity development and training on conservation techniques must be accentuated. It is therefore, recommended that future research be undertaken on the extent to which the effects of climate change affect farmer's productivity as well as the lack of youth involvement in agricultural production in the study area.
\end{abstract}

Keywords: Decision making, smallholder farmers, households, determine, education, approaches

\section{Introduction}

The agricultural sector is one of the key drivers of rural and economic development across the world. In the recognition of this sector as a key to rural and economic development, three pillars of agriculture have been identified, namely: poverty alleviation, food security and employment creation, skills development, and economic development (Agholor and Obi, 2013; Shah et al., 2020). In the rural areas, agriculture is the main economic activity and it's the very main means of escape from poverty (FAO, 2015). On the other hand, the production of food for food security is pioneered in the sector through the pillars of sustainable agriculture and other agricultural initiatives aimed at ensuring household food security (Muzangwa et al., 2017; FAO, 2018). However, the variations of climatic patterns across the world have been estimated to have impact in reducing the farm income, yields and increasing poverty levels (Henry et al., 2012; Zwane, 2018). Climate change have not only dealt badly 
with the agricultural sector, but also the natural environment and human structures it supports (Bindoff et al., 2013; Robinson, 2018). Food producers across the world have witnessed declines in agricultural output, high infestation of pests and diseases and the extreme weather patterns such as extreme temperatures and increased drought and flood seasons (Kumar et al., 2016; Zwane 2018; Pareek et al., 2020). It is an undisputable fact that all these impacts of climate change compromise the agricultural sector at a core and leaves farmers more vulnerable. This state of vulnerability may lead to farmers leaving the sector as a result of the overwhelming effects of climate change.

In as much as climate change have negatively influenced agricultural productivity, Kumar et al., (2016) argues that farmers across the world can chose to mitigate and adapt to the era of the changing climate. Climate change adaptation is the call of the day in recent years. Climate change adaptation strategies have been submitted by researchers in recent literature and that includes: Water-Smart Agriculture (WaSA), Digital Agriculture (DA), Precise Agriculture (PA), Climate-Smart Agriculture (CSA), as well as Conservation Agriculture (Mar et al., 2018; Pareek et al., 2020; Rho et al., 2020). This climate change adaptation strategies seeks to reduce the emissions of chlorofluorocarbons, solarization and keeping agriculture green. Conservation Agriculture (CA), amongst the known climate change adaptation strategies is the most efficient and const effective (FAO, 2015). CA is said to be efficient and cost effective due to its capability to deliver to the sustainable agriculture objectives. Particularly, the conservation of the natural resources, while producing for human and animal consumption as well as generation of income. The use of CA is very practical, considering its three pillars, namely: maintaining almost permanent soil cover, crop rotation (crop alterations, intercropping, multi-cropping and incorporation of crop residues into the soil) and minimum soil disturbances (zero to minimum tillage). These pillars of CA help in the preservation of soil carbon and moisture, enhancement of soil fertility, reduction of soil erodibility, and in overall, enhancement of agricultural productivity (FAO 2015; Pareek et al., 2020). Therefore, CA in the current age of the ever-changing climatic conditions promises to be the way of escape for the agricultural producers. Little is known about the adoption of CA towards climate change adaptation in South Africa, especially, in Mpumalanga Province. Hence, this paper, purposed to assess the adoption of CA towards climate change adaptation in Nkomazi Local Municipality, in Mpumalanga province. The main objectives for this study were: 1) to examine the CA approaches adopted by farmers towards climate change adaptation in the study area and 2) to determine the adoption behavior of smallholder farmers towards the adoption of CA in the study area.

\section{Materials and methods}

\section{Choice of study site}

The study was conducted at Nkomazi local municipality, which is one of the four local municipalities in the Ehlanzeni district (Figure 1). The other three Local Municipalities are: Mbombela Local Municipality, Bushbuckridge Local Municipality and Thaba Chweu Local Municipality. The study site is known of its robust agricultural engagements, which includes both the production of crops (vegetables, agronomic and fruit crops) and livestock both small and large stock). The study area is situated across the boarders of South Africa, Mozambique, and Swaziland. The respondents were randomly sampled from 17 rural communities out of 32 (Table 1). The study was conducted in seventeen (17) communities in the Nkomazi Local Municipality, namely: Buffelspruit, Schoemansdal, Jeppes Reef, Middelplaas, Naas, Block A, Block B, Block C, Mzinti, Langeloop, Boschfontein, 
Mangweni, Masibekela, Mbuzini, Hhoyi, Magogeni, and Phiva (Nkomazi Local Municipality Report 2017). Nkomazi local municipality as stated above, is part the Ehlanzeni District, which is one of the three Districts in Mpumalanga province, namely: Ehlanzeni, Gert Sibande, and Nkangala Districts (Statistics South Africa, 2011). Furthermore, the study site has total area $4787 \mathrm{~km}^{2}$, and has a total population of 393030 individuals, blacks (97,7\%), whites (1.6\%), Indians and coloureds together (0.4\%) (Statistics SA, 2011). The main languages spoken in the study area are: Siswati, Isizulu, English, Afrikaans and XiTsonga. Majority of the households are involved in agricultural activities (both crop and animal production), however, smallholder farmers registered with the Department of Agriculture are 1103 (DARDLEA, 2020).

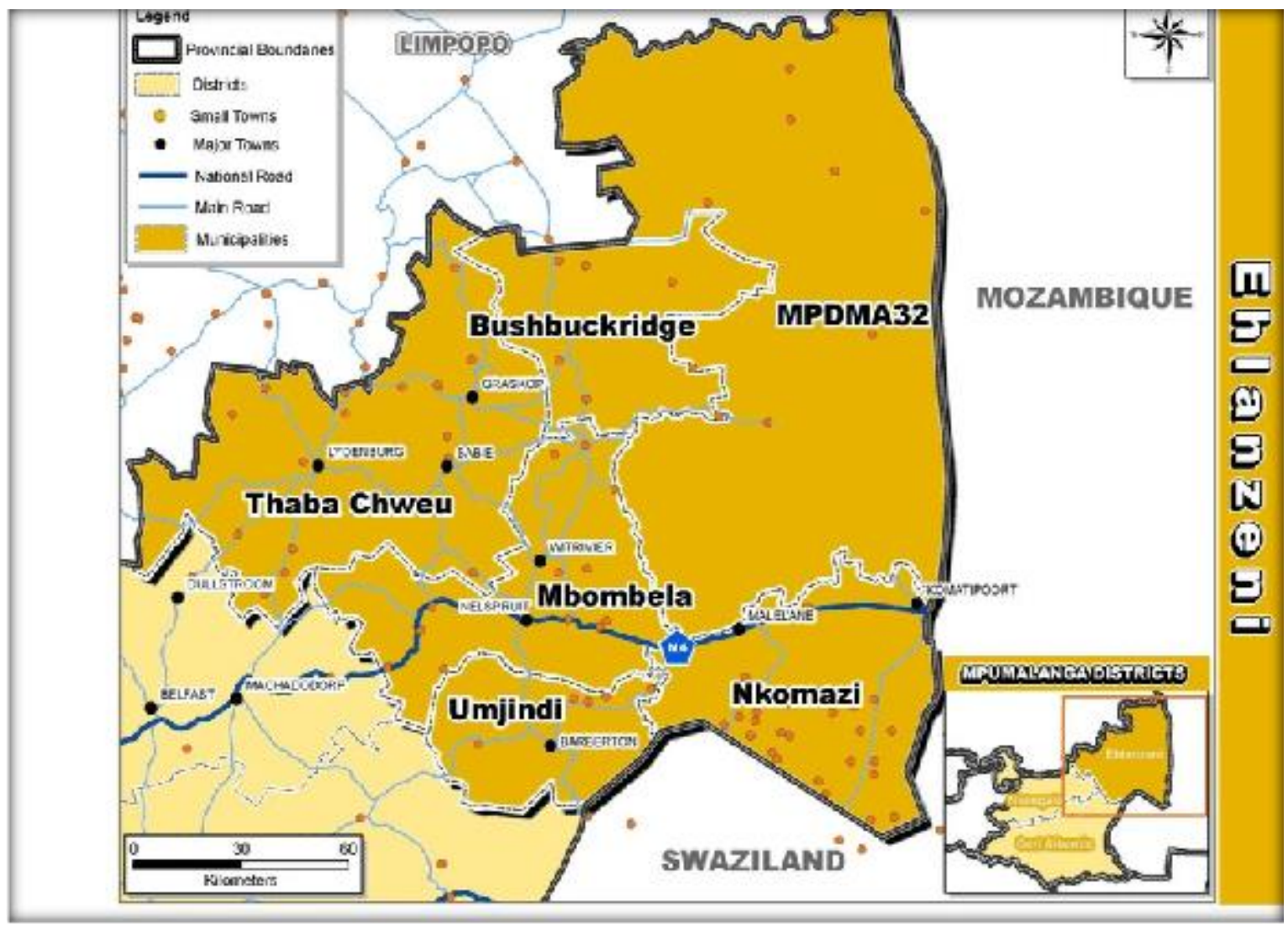

Figure 1: Map of Nkomazi Local Municipality (Mpumalanga Province)

Source: Nkomazi Local Municipality (2017)

\section{The sampling procedures and sample size for the study}

A total of 366 respondents were randomly sampled from the 1103 smallholder farmers situated in Nkomazi Local Municipality. The respondents were sampled from seventeen rural communities within the study area as reflected above. Moreover, the sample size was determined through the use of the formulae shown below. Upon the determination of the sample size, the researchers decided to increase the sample size from 294 to 366 to ensure reliability and validity of the results, to maintain consistency and be able to generalize the findings within the area of the study as well as the 
peculiarity of the project. Furthermore, a confidence level of $99 \%$, with a margin of error of 0.05 was assumed for this project.

$$
n=\frac{N}{1+N e^{2}}=\frac{1103}{1+1103(0.05)^{2}}=293.546=294
$$

n - Sample size (294)

$\mathrm{e}$ - Margin of error (0.05)

$\mathrm{N}$ - Total population (1103)

\section{Methods of data collection}

The study employed the mixed method approach, which comprises of both the qualitative and quantitative research designs. Structured questionnaires were used to collect quantitative data for the project and the Participatory Rural Appraisal (PRA) tools were also used to collect data for the survey. Transect walk were employed by the researchers in observing the entire community with the aid of community map and informant to identify areas where agricultural activities were common. Timeline and trend analysis were also employed (trend analysis to interpret the changes and trends in the community, while timeline captured the sequence of events as recalled by the local community. Venn diagram was also used to show the main institutions and individuals, opinion leaders and their relationship with the community. Focus group discussions were held during the reconnaissance survey to understand the patters and practices of farming employed by the smallholder farmers in the study area. This also assisted to assess the farming objectives of the rural people and how they aim to achieve their objectives.

\section{Methods of data analysis}

The Scientific Package for Social Science (SPSS) was used for the analysis of the data collected from the study area. In addition, descriptive statistics comprising of the frequency, percentages, bar graphs, pie charts and frequency tables. However, logistic regression, specifically, nominal regression analysis was employed to determine the adoption behavior of smallholder farmers towards the use of CA.

\section{The adopted model for the study}

The nominal logistic model employed in this study as quantified in equations below, illustrates the factors influencing smallholder farmers' adoption behavior towards CA. According to Afifi et al. (2004) logistic regression models estimates the likelihoods of events as a function of a set of descriptive variables that are hypothesized to influence an outcome. The logistic regression model has gained popularity to date and it is employed to categories individuals into either one or more populations when only one set of predictor variables is known as well as to determine which features 
best predict the adoption behavior. There are, however, no assumptions made with respect to the distribution of the predictor variables (X). However, $\mathrm{X}$ variables may be discrete or continuous (Afifi et al., 2004). Logistic regression approach is well established in empirical studies that seek to establish the determinants of the adoption behavior of smallholder farmers towards CA (Krishnapuram et al., 2005). Subsequently, let $\mathrm{R}$ represent a dichotomous variable that would be equal to 1, if the smallholder farmer adopts $\mathrm{CA}$ and 0 other wise. Furthermore, the likelihood of the choice to adopt or not to adopt CA is derived as illustrated below. The study aimed to determine whether there is an existing relationship between the farmers demographics and the adoption of CA. logistic regression is considered ideal when the is a mixture of numerical and categorical variables. The technique that was implored in determining the adoption behavior of smallholder farmers is described below:

$Y=\beta_{0}+\beta_{1} X_{1}+\beta_{2} X_{2}+\beta_{3} X_{3}+\beta_{4} X_{4}+\beta_{5} X_{5}+\beta_{6} X_{6}+\beta_{7} X_{7}+\beta_{8} X_{8}+\beta_{9} X_{9}+\beta_{10} X_{10} \mu$.

Where:

$\mathrm{Y}=$ the choice to adopt or not to adopt conservation agriculture (Farmer adopting $\mathrm{CA}=1$, and $0=$ otherwise).

$\mathrm{X}_{1}-\mathrm{X}_{11}=$ Independent variables, which have been demarcated as follows:

$\mathrm{X}_{1}=$ Age (years a farmer lived)

$\mathrm{X}_{2}=\operatorname{Gender}($ Male $=0$, Female $=1)$

$\mathrm{X}_{3}=$ Marital status (a state of being married or not married: Married $=0$, Single $=1$, Divorced $=2$, Widowed $=3$ and Engaged $=4$ )

$\mathrm{X}_{4}=$ level of education (level of educational attainment: No school $=0$, Adult school $=1$, Primary school $=2$, Secondary school $=3$ and Tertiary education $=4$ )

$\mathrm{X}_{5}=$ Farming experience (number of years in farming operations)

$\mathrm{X}_{6}=$ farmland size (number of hectares farmer owns)

$\mathrm{X}_{7}=$ Conservation Agriculture benefits (Most often $=0$, Very often $=1$. Undecided $=2$, Often $=3$ and Less often $=4$ )

$\mathrm{X}_{8}=$ Access to information $($ Most often $=0$, Very often $=1$, Undecided $=2$, Often $=3$ and Less often $=4)$

$\mathrm{X}_{9}=$ Skills $($ Most often $=0$, Very often $=1$, Undecided $=2$, Often $=3$ and Less often $=4)$

$\mathrm{X}_{10}=$ Infrastructure $($ Most often $=0$, Very often $=1$, Undecided $=2$, Often $=3$ and Less often $=4)$

$\mathrm{X}_{11}=$ External support (support from external bodies: Most often $=0$, Very often $=1$, Undecided $=2$, Often $=3$ and Less often $=4$ ) 
$\beta_{0}=$ is the constant

$\beta_{1}-\beta_{2}=$ is the standardized partial regression coefficients

$\mu=$ error term.

Table 1: The predictor variables hypothesized with their operational descriptions and measurements

\begin{tabular}{|c|c|c|c|}
\hline Variable and code & Operational description & Measurement units & $\begin{array}{l}\text { Expected } \\
\text { sign }\end{array}$ \\
\hline Age (AGE) & The number of years & Number & \\
\hline Gender (GENDR) & Respondent: male or female & $0=$ male and $1=$ female & + \\
\hline $\begin{array}{l}\text { Marital status } \\
\text { (MERITS) }\end{array}$ & $\begin{array}{l}\text { State of being married or not } \\
\text { married }\end{array}$ & $\begin{array}{l}0=\text { married; } 1=\text { single } ; 2= \\
\text { divorced; } 3=\text { widowed; } 4= \\
\text { engaged }\end{array}$ & + \\
\hline $\begin{array}{l}\text { Level of education } \\
\text { (EDUC) }\end{array}$ & Level of educational achievement & $\begin{array}{l}0=\text { no school; } 1=\text { primary } \\
\text { education; } 2=\text { secondary } \\
\text { education; } 3=\text { tertiary } \\
\text { education }\end{array}$ & + \\
\hline $\begin{array}{l}\text { Conservation } \\
\text { Agriculture benefits }\end{array}$ & $\begin{array}{l}\text { The state of being aware or not } \\
\text { aware of the benefits of } \\
\text { conservation agriculture }\end{array}$ & $\begin{array}{l}0=\text { Most often; } 1=\text { Very often; } \\
2=\text { Undecided; } 3=\text { Often; } 4= \\
\text { Less often }\end{array}$ & + \\
\hline Farm size (FAMSZ) & Size of farmland & Number & + \\
\hline $\begin{array}{l}\text { Farming experience } \\
\text { (FAMEXP) }\end{array}$ & $\begin{array}{l}\text { The number of years involved in } \\
\text { agricultural activities }\end{array}$ & Number & + \\
\hline Skills & The state of having no skills & $\begin{array}{l}0=\text { Most often; } 1=\text { Very often; } \\
2=\text { Undecided } 3=\text { Often } 4= \\
\text { Less often }\end{array}$ & - \\
\hline Infrastructure & $\begin{array}{l}\text { The state of having or not having } \\
\text { infrastructure }\end{array}$ & $\begin{array}{l}0=\text { Most often } ; 1=\text { Very often; } \\
2=\text { Undecided } 3=\text { Often } ; 4= \\
\text { Less often }\end{array}$ & + \\
\hline External support & $\begin{array}{l}\text { The state of having access or not } \\
\text { having access to support from } \\
\text { external bodies }\end{array}$ & $\begin{array}{l}0=\text { Most often; } 1=\text { Very often; } \\
2=\text { Undecided } 3=\text { Often; } 4= \\
\text { Less often }\end{array}$ & + \\
\hline
\end{tabular}

\section{Results and Discussion}

\section{Socio-economic characteristics of the smallholder farmers in the study area}

Table 2, below, shows the farmers' socio-economic characteristics of the farmers in the study area. The findings reveal that of all the 366 respondents, $63.7 \%$ are females, while only $36.3 \%$ are males. Significantly, the findings reflect the gender of both the youths and the old persons involved in agricultural activities in the study area. It was further discovered during the focus group discussions that females are into agricultural activities due to some domestic reasons and such involves: single parenting due to loss of spouse to death, spouse having left the village for white collar jobs, and 
individual farmer being single. The study agrees with Kalungu et al. (2013) who asserted that women are more involved in agricultural activities than men. Of all the respondents, $38.50 \%$ are within the age group of $36-55$ years. This marks the majority of the farmers in the study area and it proves that the issue of having more old persons as farmers is being addressed. Findings further reveals that of the 366 respondents, $47.27 \%$ are married, with $38.52 \%$ single farmers. Majority of the farmers in the study area have only up to secondary education. While, only $8.70 \%$ of the farmers have up to tertiary education in the study area. This result is in agreement with Azam (2015); Agholor and Sithole (2020) in whose studies, it was discovered that majority of farmers in the rural areas have only up to secondary education.

It is further revealed by the results (Table 2) that majority of the farmers in the study area have household size of $3-5$ persons each. This result shows consistence with Jona (2016) whose study confirmed that majority of farming families are of larger family sizes. This could possibly be as a result that the family farms together and assists each other in the farming operations. Out of all the 366 respondents, $79.00 \%$, which marks the majority of the farmers, have their primary source of income as farming. This result lead credence to Sebeho (2016) who postulated that the main source of income for farmers is farming business. The water used by the farmers in the study area are from different sources. $29.50 \%$ of the farmers use water from the river, while $6.60 \%$ of the farmers use water sourced from boreholes in their farms. It was further discovered during the focus group discussions that the rivers supplying water to the farmers in the Nkomazi area are: Nkomazi River, Ngugwane River, Mlumati River, Mzinti River and Mtilane River. Significantly, from the Driekoppies dam, Ngugwane dam and the Mbambiso dam, only $6.00 \%$ of the farmers extracts irrigation water.

Table 2: Socio-economic characteristics of the smallholder farmers in the study area

\begin{tabular}{|c|c|c|}
\hline Variable & Categories & Percentages (\%) \\
\hline \multirow{2}{*}{ Gender } & Male & $36.39 \%$ \\
\hline & Female & $63.70 \%$ \\
\hline \multirow{4}{*}{ Age } & $18-35$ years & $17.50 \%$ \\
\hline & $36-55$ years & $38.50 \%$ \\
\hline & $56-75$ years & $39.30 \%$ \\
\hline & $>75$ years & $4.60 \%$ \\
\hline \multirow{5}{*}{ Educational level } & No school & $21.00 \%$ \\
\hline & Adult school & $1.60 \%$ \\
\hline & Primary education & $24.90 \%$ \\
\hline & Secondary education & $43.70 \%$ \\
\hline & Tertiary education & $8.70 \%$ \\
\hline \multirow[t]{5}{*}{ Marital status } & Married & $47.27 \%$ \\
\hline & Single & $38.52 \%$ \\
\hline & Divorced & $0.82 \%$ \\
\hline & Widow & $11.48 \%$ \\
\hline & Widower & $1.91 \%$ \\
\hline
\end{tabular}




\begin{tabular}{|c|c|c|}
\hline \multirow[t]{4}{*}{ Household size } & $1-2$ persons & $7.10 \%$ \\
\hline & $3-5$ persons & $47.54 \%$ \\
\hline & $6-10$ persons & $32.24 \%$ \\
\hline & More than 10 persons & $13.11 \%$ \\
\hline \multirow[t]{7}{*}{ Source of income } & Employed (off-farm activities) & $3.60 \%$ \\
\hline & Self-employed & $2.20 \%$ \\
\hline & Farming & $79.00 \%$ \\
\hline & Unemployed & $1.90 \%$ \\
\hline & Social grant & $1.10 \%$ \\
\hline & Pension & $5.50 \%$ \\
\hline & Other & $6.80 \%$ \\
\hline \multirow{5}{*}{ Farmland size } & $<1$ hectare & $34.20 \%$ \\
\hline & $1-5$ hectares & $52.10 \%$ \\
\hline & $6-10$ hectares & $10.70 \%$ \\
\hline & $11-20$ hectares & $1.40 \%$ \\
\hline & $>20$ hectares & $1.40 \%$ \\
\hline \multirow{4}{*}{ Water source } & Borehole & $6.60 \%$ \\
\hline & River & $29.50 \%$ \\
\hline & Dam & $6.00 \%$ \\
\hline & Other & $57.90 \%$ \\
\hline
\end{tabular}

Conservation Agriculture Approaches used by farmers in the study area

Table 3: the CA approaches used by farmers in the study area

\begin{tabular}{llll}
\hline & Frequency & & Cumulative Percent \\
\hline Minimal tillage & 29 & 7.9 & 7.9 \\
\hline Mulching & 19 & 5.2 & 13.1 \\
\hline Crop rotation & 228 & 62.3 & 75.4 \\
\hline Rain water harvesting & 3 & .8 & 76.2 \\
\hline Intercropping & 4 & & 77.3 \\
\hline Other & 39 & 10.7 & 88.0 \\
\hline Total & 44 & 12.0 & 100.0 \\
\hline
\end{tabular}

Table 3, above, presents results on the CA approaches employed by respondents in their farms in the study area. Findings reveals that majority of the respondents employ crop rotation as compared to the other CA approaches. Findings reveals that $62.30 \%$ of the 366 respondents who participated in the study uses crop rotation. On the other hand, cover cropping with only $1.10 \%$ of the respondents, is one of the less used of the CA approaches in the study area. In as much as cover cropping is used by few respondents in the study area, it comes after rain-water harvesting which is used by only $0.80 \%$ of 
the 366 respondents in the study area. Findings reveals that $7.90 \%$ of the respondents employs minimum tillage approach, while $5.20 \%$ of the respondents employs mulching approach. Findings further reveals that $10.70 \%$ of the respondents asserted that they use intercropping in their farms, while $12.00 \%$ of the respondents uses CA approaches. It was further discovered during the focus group discussions that the respondents employ crop rotation because it is the one, they mostly used to. Furthermore, the knowledge on how to best use the CA approaches is not well known amongst respondents in the study area. These findings further satisfy the first objective of the study which is to examine the CA approaches used by smallholder farmers in the study area in mitigating the effects of climate change. This result lead credence to Muzangwa et al., (2017) who stated that majority of rural farmers does practice CA, especially, crop rotation and the incorporation of crop residues back into the soil.

\section{Empirical results of the study}

Table 4, below, show the regression result employed in the determination of farmers' decisions to adopt CA. In most studies, models with categorical dependent variable, the computation of single R2 statistics that has all characteristics of R2 is impossible, so approximations are made instead, and therefore, this study adapted this approach. As indicated in table 4, the Pseudo R2 shows a summary of the proportion of variance of the dependent variable which is associated with the predictor (independent) variables. With Cox and Snell (0.415), McFadden (1.00) and Nagelkerke R2 of 1.000 results obtained, show that more of the variables were clarified in the model and that the model fit this study (Nagelkerke,1991). However, in the study, nine independent variables were positive and significant but negatively influence adoption of CA practice with the exception of farmland size and age of the farmers. These are: gender, level of education, farming experience, lack of access to information, lack of skills, lack of infrastructure, and the farmers awareness of Conservation Agriculture benefits. Marital status of farmers was tested as a predictor variable; however, findings shows that it was not significant in the adoption behavior of farmers.

Nominal regression, nine variables (age, level of education, farming experience, farmland size, the lack of skills, benefits of conservation agriculture, lack of infrastructure, lack of external support and lack of access to information) out of the eleven variables used were found to be significantly influencing the adoption of conservation agriculture in the study area. While only one variable (marital status) was not significant (Table 4). Significantly, out of the nine variables which were significantly influencing the adoption behavior of the respondents in the study area, six variables were found to have negative signs, which by implications means, that at an increase of each of these, the is more likeliness of decline in the adoption of conservation in the study area. On the other hand, three variables were found to have a positive sign, which by implication means that at an increase of either of the variables, there is more likeliness of an increase in the adoption of conservation agriculture in the study area. 
Table 4: The empirical results of the study

\begin{tabular}{|c|c|c|c|c|c|c|c|c|}
\hline \multicolumn{9}{|l|}{ Parameter Estimates: } \\
\hline \multirow[t]{2}{*}{ Independent Variables } & \multirow[t]{2}{*}{$\beta$} & \multirow[t]{2}{*}{ Std. Error } & \multirow[t]{2}{*}{ Wald } & \multirow[t]{2}{*}{$\mathrm{df}$} & \multirow[t]{2}{*}{$\mathrm{P} \leq$} & \multirow[t]{2}{*}{$\operatorname{Exp}(B)$} & \multicolumn{2}{|c|}{$\begin{array}{l}\text { 95\% Confidence } \\
\text { Interval for } \operatorname{Exp}(B)\end{array}$} \\
\hline & & & & & & & $\begin{array}{l}\text { Lower } \\
\text { Bound }\end{array}$ & $\begin{array}{l}\text { Upper } \\
\text { Bound }\end{array}$ \\
\hline Intercept & 131.916 & 4.308 & 937.711 & 1 & .000 & & & \\
\hline Age of respondents & 3.086 & .556 & 30.816 & 1 & .000 & 21.889 & 7.363 & 65.077 \\
\hline Gender of respondents & -5.429 & 2.319 & 5.480 & 1 & .019 & .004 & $4.659 \mathrm{E}-5$ & .413 \\
\hline $\begin{array}{l}\text { Marital status of } \\
\text { respondents }\end{array}$ & .102 & .906 & .013 & 1 & .911 & 1.107 & .187 & 6.539 \\
\hline $\begin{array}{l}\text { Level of education of } \\
\text { respondents }\end{array}$ & -4.892 & .343 & 203.255 & 1 & .000 & .008 & .004 & .015 \\
\hline $\begin{array}{l}\text { Farming experience of } \\
\text { respondents }\end{array}$ & -8.650 & .386 & 501.372 & 1 & .000 & .000 & $8.215 \mathrm{E}-5$ & .000 \\
\hline $\begin{array}{l}\text { Farmland size of } \\
\text { respondent }\end{array}$ & 2.261 & .736 & 9.441 & 1 & .002 & 9.592 & 2.268 & 40.571 \\
\hline $\begin{array}{l}\text { Conservation Agriculture } \\
\text { benefits }\end{array}$ & -.796 & .174 & 21.010 & 1 & $\begin{array}{l}.000 * \\
*\end{array}$ & .451 & .321 & .634 \\
\hline $\begin{array}{l}\text { Lack of infrastructure as a } \\
\text { constraint }\end{array}$ & -4.000 & .367 & 118.910 & 1 & $\begin{array}{l}.000 * \\
*\end{array}$ & .018 & .009 & .038 \\
\hline $\begin{array}{l}\text { Lack of external support as } \\
\text { a constraint }\end{array}$ & -3.624 & .673 & 29.010 & 1 & $\begin{array}{l}.000 * \\
*\end{array}$ & .027 & .007 & .100 \\
\hline $\begin{array}{l}\text { Lack of access to } \\
\text { information as a constraint }\end{array}$ & -9.307 & .375 & 614.668 & 1 & .000 & $9.083 \mathrm{E}-5$ & $4.352 \mathrm{E}-5$ & .000 \\
\hline $\begin{array}{l}\text { Lack of skills as a } \\
\text { constraint }\end{array}$ & 3.105 & .615 & 25.465 & 1 & .000 & 22.311 & 6.680 & 74.522 \\
\hline \multicolumn{9}{|l|}{ Pseudo R2 } \\
\hline Cox and Snell & .415 & & & & & & & \\
\hline Nagelkerke & 1.000 & & & & & & & \\
\hline McFadden & 1.000 & & & & & & & \\
\hline
\end{tabular}

Note: The significance variables influencing the adoption behaviour at $0.005(* *)$ and $0.1(*)$ significance levels.

The study used gender as an independent variable (Table 4) and was significant with a P-value of $(0.19)$, but negatively related to the adoption behaviour of the respondents with a co-efficient of (5,429). the study of Conradie et al. (2013) and Agholor and Nkosi (2020) who found that gender is significant in the adoption of new farming technologies. Age as an independent variable was found to be significant with a P-value of (0.000), and positively related to the adoption behaviour of the respondents with a co-efficient of 3.086. This result agrees with Agholor and Sithole (2020) who posited that an increase in age of farmers increases the likelihood of adoption of water conservation. The level of education was significant associated with a P-value of (0.000), but negatively related to 
the adoption behaviour of the respondents with a co-efficient of (-4.892). The results contradict the finding of Azam (2015) who found that an increase in the level of education of farmers increases the probability of adoption of new farming technologies. The farming experience of the respondents was used as an independent variable in the study. The farming experience of the respondents was significant with a P-value of (0.000), but negatively related to the adoption behaviour of the respondents with a co-efficient of (-8.650). The respondents' farmland size was used in the study as an independent variable. It is measured as a nominal variable and was found to be significant, with a P-value of (0.002) and positively related to the adoption behaviour of the respondents, with a coefficient of (2.261). This implies that with an increase in the farmland size of the respondents, there is a likelihood that the adoption of conservation agriculture increases by 2.261 times. This result is therefore, in divergence with Gailhard et al. (2015) who suggested that an increase in the farmland size increase the adoption likelihood of farmers. The respondents' lack of access to information was used as an independent variable in this study and is measured as a scale. It was found to be significant, with a P-value of (0.000), but negatively related to the adoption behaviour of the respondent, with a co-efficient of (-9.307). These results, is in agreement with Nyamangara et al. (2013) who postulated that the lack of access to information decreases the adoption likelihood of farmers.

\section{Conclusion and recommendation}

Climate change is a threat to agricultural productivity and the overwhelming effects of climate change hinders the quest for sustainable agriculture, with the aim of satisfying the increasing demands for food and fiber. Adaptation to the ever-changing climate is a necessity for the agricultural sector. The study was conducted in Nkomazi Local Municipality. The study assessed the adoption of conservation agriculture in relation to climate change by smallholder farmers. Furthermore, the objectives of the study were to examine the conservation agriculture approaches used in mitigating the impact of climate change by the farmers in the study area and to investigate the adoption behavior of smallholder farmers in the study area. The predictor variables used in investigating the adoption behavior includes the age, gender, level of education, marital status, farmland size and farming experienced of the farmers. Moreover, focus group discussion, structured and semi-structured questionnaires were used to randomly collect data from selected smallholder farmers. The data was analyzed using the binary logistics regression model to determine adoption behavior of farmers in the use of conservation agriculture. Logistic regression result show that several predictor variables were found to significantly influence the adoption behavior of smallholder farmers in the area. The study noted the existence of significant variables to include age, education, farmland size and the lack of access to information. Furthermore, thoughtful decision process and smallholder farmers' capacity development and training on conservation techniques must be accentuated. Findings shows that age, gender, farming experience, level of education of farmers and the benefits of conservation agriculture to be positive and significant in influencing the adoption behavior of farmers in the study area, towards the adoption of CA approaches. Marital status of the farmers was found not to be significant and never to influence the adoption behavior of farmers with a p-value of (0.911) and co-efficient of (0.102). Therefore, it is recommended that future research be undertaken on the extent to which the effects of climate change affect farmers' productivity. There is need to investigate the lack of the youth involvement in agricultural production in the study area. 


\section{Acknowledgement}

The authors would like to acknowledge the University of Mpumalanga for the release of the ethical clearance for the project as well as funding the authors in attendance of the AGRICO2021 conference.

\section{References}

Afifi, A., Nofal, Z., \& Butt, N. (2014). Transumuted complementary weibull geometric distribution. Pakistan Journal of Statistics and Operation Research, 10(4). 435-454.

Agholor, A., \& Nkosi, M. (2020). 'Sustainable Water Conservation Practices and Challenges amongst Smallholder Farmers in Enyibe Ermelo Mpumalanga Province, South Africa'. Journal of Agricultural Extension, Vol. 24 (2), 112 - 123.

Agholor, A., \& Obi, A. (2013). The storm of poverty reduction strategy in Africa: Chronology of experiences from South Afroca. Journal of Agricultural Science, 5(2). 85-94.

Agholor, A., \& Sithole, M. (2020). "Tillage Management as a Method of Weed Control in Mangweni, Nkomazi Local Municipality, South Africa”. International Journal of Sciences and Research, Vol. 76 (7), $209-221$.

Azam, M. (2015). "The Influence of Socio-Demographic Factors in Adoption of Organic Farming Practices". International Journal of Interdisciplinary and Multidisciplinary Studies, Vol. 2 (5), $8-17$.

Bindoff, N., Stott, P., AchutaRao, K., Allen, M., Gillett, N., \& Gutzler, D. (2013). 'Detection and Attribution of Climate Change: From Global to Regional'. In: Stocker TF et al. (eds.) Climate Change 2013: The Physical Science Basis', Contribution of Working Group I to the Intergovernmental Panel in Climate change. United Kingdom and New York. NY, USA: Cambridge University Press.

Conradie, B., Piesse, J., Thirtle, C., Vink, N., \& Winter, K. (2013). Explaining declining agricultural total factor productivity in the Karoo districts of Western Cape, 1952 to 2002. Agrekon, 52 ( sup1). 1-23.

Department of Agriculture, L. R. (2020). DARDLEA registered smallholder farmers in Nkomazi Local Municipality. Mbombela: Unpublised raw data.

FAO. (2015). 'Food and Agriculture Organization of the United Nations: Conservation agriculture'. Retrieved from http://www.fao.org/ag/ca/6c.html. Accessed on the 26th April 2020

FAO. (2018). 'Climate Smart Agriculture: Building Resilience to Climate Change'. USA: Berkeley.

Gailhard, I., Bovorova, M., \& Pirscher, F. (2015). "Adoption of Agri-Environmental Measures by Organic Farmers: The Role of Interpersonal Communication”. Journal of Agricultural Education and Extension, Vol. 21 (2), 127 - 148.

Henry, B., Charmley, E., Eckard, R., Gaughan, J., \& Hegarty, R. (2012). 'Livestock Production in a Changing Climate: Adaptation and Mitigation in Australia'. Crop and Pasture Science, 6 (3), $191-202$.

Jona, C. (2016). "Developing a Framework for Improving Coordination in the Provision of Agricultural Support Services to Farmers in the Oshikoto Region, Namibia”. University of Pretoria, South Africa: PhD thesis, Faculty of Natural and Agricultural Sciences.

Kalungu, J., Leal, W., \& Mwangi, M. (2013). Responding to food production challenges in the face of global warming at community level in Kenya: the role of local University . Springer, Dordrecht, 231-241.

Krishnapuram, B., Carin, L., Figueiredo, M., \& Hartemink, A. (2005). Sparse multinomial logistic regression: Fast algorithms and generalization bound. IEEE transaction on pattern analysis and machine intelligence, 27(6), 957-968. 
Kumar, S., Choudhary, M., Ghasal, P., Yadav, R., Singh, S., Meena, S., \& Bisht, J. (2016). Conservation Agriculture and Climate Change: An Overview'. ResearchGate, Publication: 311418457.

Mar, S., Nomura, H., Takahashi, Y., Ogata, K., \& Yabe, M. (2018). 'Impact of Erratic Rainfall from Climate Change on Pulse Production Efficiency in Lower Myanmar'. JEB, Vol. 71 (1), 443 450 .

Muzangwa, L., Mnkeni, P., \& Chiduza, C. (2017). 'Assessment of Conservation Agriculture Practices by Smallholder Farmers in Eastern Cape Province of South Africa' . MDPI, 7 (46), doi.103390.

Nagelkerke, N. (1991). A note on a general defination of the coefficient of determination . Biometrika, 78(3), 691-692.

Nkomazi Local Municipality. (2017). 'Draft Annual Report 2016/2017'. South Africa: Nkomazi.

Nyamangara, J., Chkowo, R., Rusinamhodzi, L., \& Mazvimavi, K. (2013). 'Conservation Agriculture in Southern Africa'. ResearchGate, Accessed from: http://www.researchgate.net/publication/272351008. Accessed on the 2nd May 2020.

Pareek, A., Dhankher, O., \& Foyer, C. (2020). 'Mitigating the Impact of Climate Change on Plant Production and Ecosystem Sustainability'. JEB, Vol. 71 (2), 451 - 456.

Rho, H., Dotty, S., \& Kim, S. (2020). 'Endophytes Alleviate the Elevated CO2 Dependent Decrease in Photosynthesis in Rice, Particularly Under Nitrogen Limitation'. JEB, , 71, 707 - 718.

Robinson, S. (2018). 'Adapting to Climate Change at the National Level in Caribbean Small Island Developing States'. Island Studies Journal , 13 (1), 79 - 100.

Sebeho, M. (2016). "Perception and Attitude of Farmers and Extensionists towards Extension Service Delivery in the Free State Province, South Africa", . University of Pretoria, South Africa: Master Thesis, Faculty of Natural and Agricultural Sciences.

Shah, K., Dulal, H., \& Awatobi, M. (2020). 'Food Security and Livelihood Vulnerability to Climate Change in Trinidad and Tobago'. USA: Springer Nature Singapore Publishers.

Statistics, S. A. (2011). Mid- year population exstimates for South Africa. Pretoria: Statistics South Africa.

Zwane, T. (2018). Assessing the determinants and effects of non-monetary household asset poverty in South Africa. Johannesburg: University of Johannesburg, South Africa. 